\title{
Asset Prices and the Financial Crisis of 2007-2009: Overview of Theories and Policies
}

Anastasios G. Malliaris

Loyola University Chicago, tmallia@luc.edu

Daniels Hayford

University of Tennessee

Follow this and additional works at: https://ecommons.luc.edu/business_facpubs

Part of the Business Commons

\section{Author Manuscript}

This is a pre-publication author manuscript of the final, published article.

\section{Recommended Citation}

Malliaris, Anastasios G. and Hayford, Daniels. Asset Prices and the Financial Crisis of 2007-2009:

Overview of Theories and Policies. Forum for Social Economics, 39, 10: 279-286, 2010. Retrieved from Loyola eCommons, School of Business: Faculty Publications and Other Works, http://dx.doi.org/10.1007/ s12143-010-9062-9

This Article is brought to you for free and open access by the Faculty Publications and Other Works by Department at Loyola eCommons. It has been accepted for inclusion in School of Business: Faculty Publications and Other Works by an authorized administrator of Loyola eCommons. For more information, please contact ecommons@luc.edu.

\section{(c) $($ †) $\ominus$}

This work is licensed under a Creative Commons Attribution-Noncommercial-No Derivative Works 3.0 License.

(c) Taylor \& Francis 2010 


\title{
ASSET PRICES AND THE FINANCIAL CRISIS OF 2007-09: AN OVERVIEW OF THEORIES AND POLICIES
}

\author{
Marc D. Hayford \\ A.G. Malliaris \\ Department of Economics \\ Loyola University Chicago \\ 1 East Pearson Street \\ Chicago, Illinois 60611
}

\begin{abstract}
The financial crisis of 2007-09 has led to a rethinking of the role of monetary and financial regulatory policy. It has also called into question the benefits of financial innovation and monetary policy that focuses solely on inflation and the output gap. This paper discusses financial instabilities in general, the recent financial crisis as well as the appropriate role of monetary and financial regulatory policy in dealing with asset bubbles. The paper concludes by evaluating appropriate policies to reduce the economic impact of future financial crises.
\end{abstract}

JEL Classification: E50, E52, E58

Key Words: Asset Bubbles, Financial Crisis, Regulation,

Current Draft: January 28, 2010. This paper was presented at a session of the Association for Social Economics at the Allied Social Science Associations Meetings in Atlanta, January 2-5, 2010. The authors are thankful to Professor Betsy Jane Clary for the invitation to participate in the program and Professors John Marangos, John Tiemstra and Randal Wray who discussed the paper and offered valuable comments.

This paper has been published in the FORUM OF SOCIAL ECONOMICS, Volume 39, No. 3, October 2010. 


\section{ASSET PRICES AND THE FINANCIAL CRISIS OF 2007-09: AN OVERVIEW OF THEORIES AND POLICIES}

\section{INTRODUCTION}

The recent financial crisis and consequent "Great Recession" has resulted in economists reconsidering the role monetary policy and financial regulation play in the economy. This reconsideration follows a period of time when both economists and economic policy makers were congratulating themselves on a job seemingly well done.

In the 20 years since the disinflation of the early 1980s the U.S. economy experienced two long economic expansions and two mild recessions. In addition, the volatility of inflation and the growth rate of real GDP declined. This period, known as the "Great Moderation" also experienced episodes of financial instability such as the stock market crashes of 1987 and 2000, the S\&L crisis of the 1980s, the 1994 Mexican crisis, the 1997 Asian Financial Crisis, the 1998 LCTM bankruptcy and the 1998 Russian default. However these events had little impact on the real economy. The Fed focused largely on setting the Federal funds rate to insure maximum sustainable growth and price stability. The consensus for optimal monetary policy, sometimes called the "Greenspan doctrine" suggested that central banks respond to asset price booms asymmetrically: that is, do nothing during the asset price boom and then cut interest rates during the bust to reduce the impact on the real economy.

The Greenspan policy doctrine seemed to work well in insulating the real economy from financial instability during the 20 years since the early 1980s. Also during this twenty year period the financial sector, in response to deregulation as well as financial innovations leading to development and marketing of new financial instruments, doubled in size as measured by valued added to GDP (see table 1). While the U.S. economy did not grow faster, the variance of output growth fell even in the face of episodic financial instability which perhaps was offset by appropriately timed cuts in the Federal funds rate.

Table 1

\begin{tabular}{|c|c|c|c|c|c|}
\hline $\begin{array}{c}\text { Growth rate real } \\
\text { GDP }\end{array}$ & $1960 \mathrm{~s}$ & $1970 \mathrm{~s}$ & $1980 \mathrm{~s}$ & $1990 \mathrm{~s}$ & $2000-2008$ \\
\hline $\begin{array}{c}\text { Standard Deviation } \\
\text { of growth rate of } \\
\text { real GDP }\end{array}$ & $1.6 \%$ & $2.5 \%$ & $3.0 \%$ & $3.1 \%$ & $2.3 \%$ \\
\hline $\begin{array}{c}\text { Value added of } \\
\text { financial sector as } \\
\text { a share of GDP }\end{array}$ & $4.0 \%$ & $4.6 \%$ & $6.0 \%$ & $7.3 \%$ & $8.4 \%$ \\
\hline
\end{tabular}

In explaining the "Great Moderation" of the business cycle since the disinflation of the 1980s some economists, most prominently Bernanke (2004) cited financial 
innovation and appropriate monetary policies as two key causal factors. Financial innovation was believed to improve the performance of the economy by allocating capital and risk more efficiently. Monetary policy by appropriately timed cuts in interest rates was thought to have offset financial shocks, resulting in long economic expansions and mild recessions. Hence prior to the financial crisis of 2007-2009, the economic consensus among central bankers and many academics was that monetary policy was working, maybe even fine tuning the economy while financial innovations were resulting in a more efficient allocation of capital.

In retrospect, given the financial crisis of 2007-2008 and the resulting $2^{\text {nd }}$ Great Contraction, these explanations have lost, at least, some force. Ironically two commonly cited causes of the recent financial crisis and recession are monetary policy and financial innovation. Hence both the appropriate role of monetary policy and financial innovation are currently being rethought by economists. For monetary policy the asymmetric approach to asset price booms, which had been widely endorsed by central bankers is now being reconsidered, particularly for financial sector financed asset price booms such as in real estate. Financial innovation is also being reconsidered with an eye toward new regulation.

The rest of this paper is organized as follows: the next section discusses the general characteristics of financial crises along with various theories that have been development in an attempt to understand them. Then the recent financial crisis of 200709 is reviewed, followed by a discussion of what new policies may reduce the frequency of financial crises and their impact on the real economy.

\section{GENERAL CHARACTERISTICS OF FINANCIAL CRISES}

Financial crises are a recurring phenomenon across countries and throughout history. Crises can be thought of as having three parts: 1) initial causal factors setting up, 2) an asset price bubble and bust with implications for financial markets and 3) a propagation mechanism from the financial to the real economy.

Analysis of financial crises suggests two key initial causal factors: financial liberalization and credit expansion. For example Bordo et al. (2001) find that in the post WWII period, financial crises occur more frequently after financial deregulation and Reinhart and Rogoff (2008a, 2008b, 2009) using a data set of high and middle-to-low income countries, find that systemic banking crises are usually preceded by credit booms and asset price bubbles. Also, Kaminsky and Reinhart (1999) compare financial crises in 20 countries: 5 industrial and 15 emerging economies. They find that financial liberalization and significant credit expansion precede most of crises in their sample with a resulting average increase in the price of stocks of about 40 percent per year above that occurring in normal times. The prices of real estate and other assets also increase significantly. Eventually the stock and real estate markets collapse. In many cases banks and other intermediaries were overexposed to the equity and real estate markets and about a year later on average a banking crisis ensues. Finally, a significant decrease in output occurs with a recession that lasts about a year and a half on average. 
Hence research suggests financial liberalization plus credit expansion results initially in an increase in asset prices which may eventually cause a financial crisis provided an asset price bubble and bust cycle occurs. The price bubble can develop in either stocks or real estate or both.

Ideas about how asset price bubbles and busts occur are developed by Minsky (1986), Akerlof and Shiller (2009) and Geanakoplos (2009). Minsky proposes a credit cycle model of five stages: displacement, boom, euphoria, profit taking and panic. The displacement stage could occur due to financial liberalization and credit expansion resulting in an asset price bubble, i.e. Minsky's "euphoria". An asset price bubble occurs when an increase in asset prices causes an increase in expected future asset prices. This results in increased current demand for assets which results in further increases in prices and demand and so in a spiral that drives asset prices up. The boom or bubble is sustained so long as new buyers are available who have access to credit and who also believe asset prices will continue to rise.

Akerlof and Shiller (2009) suggest that during a bubble, beliefs that assets prices will continue to rise, spreads like an epidemic from one investor to another. Geanakoplos' (2009) model of leverage cycles suggests a link between asset prices, credit availability, and optimistic expectations: A rise in asset prices increases the value of assets as collateral. This makes banks more willing to lend, which further increases the demand for assets, particularly for the most optimistic borrowers. Increased demand for assets further increases asset prices and the asset price spiral continues. At some point all so inclined buyers have brought into the market, asset prices peak and the asset price bubble pops. For Minsky this is the "panic stage". For Geanakoplos this is an example of "scary news" which causes a sudden selling of assets resulting in falling asset prices. The decline in the wealth of leveraged buyers resulting in forced sales and a further downward spiral in asset prices. In addition in this environment banks tighten lending standards due to increased uncertainty and disagreement about the future. A similar idea was developed earlier by Kiyotaki and Moore (1997) who show that small shocks can result in large effects because of the role of collateral. A shock that lowers asset prices lowers the value of collateral. This means that less borrowing is possible, asset prices are further lowered and so on in a downward spiral.

The propagation of a bust in asset prices to the real economy depends on the involvement of the financial sector in financing the bubble. More financial sector involvement implies greater hits to financial institution balance sheets. This increases the uncertainty about lenders to bank have about bank solvency. Consequently depositors and other lenders to financial institutions start to withdraw their funds or refuse to rollover debt. This forces financial institutions to sell assets. The consequence is a downward spiral in asset prices and/or a freeze up in financial market, resulting in a decline in the actual or due to asymmetric information, perceived number of secure banks and financial institutions .

Central bank and government interventions are common events during financial crises. They prevent the bankruptcy of systemic financial institutions and prevent 
contagion. In March 2008, for example, the Federal Reserve used this argument to try to avoid the bankruptcy of Bear Sterns which occurred a few months later in September of 2008 and illustrates how damaging contagion can be. The process did not work as it was expected by the academic literature and was not accounted for in the decision of the Federal Reserve and Treasure that Lehman should not be saved. After seeing Lehman Brothers collapse, confidence in the creditworthiness of banks and other financial institutions and firms fell significantly contaminating then the real economy and resulting in a damaging effect.

Another effect of financial distress in the banking system is reduced lending to the real economy. Generally, sectors that are more dependent on external finance perform relatively worse during banking crises, provide evidence that bank distress contributes to a decline in credit and to low GDP growth, especially in developing countries and countries with less access to foreign finance where the effects are stronger. These results are consistent with the financial accelerator model of Bernanke and Gertler (1989) which provides a useful framework for thinking about the impact of tighter lending standards on the real economy. These authors argue that due to differences in the cost to lenders in borrowing from banks versus the bond market, credit market conditions can amplify and propagate shocks if borrowers lose bank financing or if a negative shock to the borrowers' wealth results in a loss of access to bank credit. Hence a financial crisis due to financial disintermediation can have a large negative impact on the real economy.

\section{THE FINANCIAL CRISIS OF 2007-09}

The financial crisis of 2007-09 shares many of the characteristics of previous crises while some of the details differ. Similar to past crises, Buiter (2007) cites credit expansion in the form of excessive global liquidity creation by key central banks and a global saving glut, brought about by the entry of a number of high-saving countries (notably China) into the global economy and a global redistribution of wealth and income towards commodity exporters that also had, at least in the short run, high propensities to save. Finally some of the unique characteristics of the crisis include fundamental flaws in the rating agencies' business model, pro-cyclical behavior of leverage in much of the financial system, and privately rational but socially inefficient disintermediation.

A detailed overview of the events preceding and during the current financial crisis is provided in Adrian and Shin (2009), Brunnermeier (2009) and Taylor (2008). These authors argue that the beginning of the current financial crisis can be related to the low interest rate policies adopted by the Federal Reserve and other central banks in the G20s after the collapse of the technology stock bubble in 2001. A contributing factor was the global savings surplus of rapidly growing Asian nations. The combination of the global savings glut and the easy monetary policy by the Fed to offset the bursting of the internet bubble contributed to a dramatic increase in the demand for housing. As in the case with previous bubbles, rising housing prices led to increased demand for housing resulting in further increases in prices, thus setting off a rising price spiral with prices increasing significantly during 2004-2006 in the U.S. and several other countries. After this bubble reached its peak in July 2006, house prices in the U.S. and elsewhere started to fall in 
early 2007. As a consequence, the prices of securitized subprime mortgages fell, affecting financial markets worldwide.

In summer 2007, U.S. and the global financial markets found themselves facing a potential financial crisis. It was becoming clear that banks and other financial institutions would ultimately lose tens or even hundreds of billions of dollars from their exposure to subprime mortgage market loans. Bank lending is closely tied to bank capital or net worth. Specifically, bank regulators require that loans do not exceed a certain multiple of capital. Thus, the Federal Reserve faced the danger of a sharp contraction in credit and bank lending in a way that threatened a recession.

The subprime mortgage meltdown started in early 2007. Bear Stearns, one of the nation's largest underwriters of mortgage bonds, experienced major financial difficulties in the summer of 2007 in two of its High Grade Structured Credit Funds. As a benchmark for the 2007 U.S. sub-prime crisis, Reinhart and Rogoff (2008) draw on data from the eighteen bank-centered financial crises from the post-War period. By comparing the run-up in housing prices prior to the financial crisis, the run-up in housing prices in the United States exceeds that of the major housing increases in the Reinhart and Rogoff (2008) sample. Once again, the United States looks like the archetypical crisis country, only more so. What caused such a large increase in housing prices remains to date a topic of intense discussion. Taylor (2008) and others claim that it was the easy monetary policy of the Fed during 2004-2006 that fueled higher housing prices while Bernanke (2010) disputes such claims.

From the perspective of risk taking measures, the average difference between U.S. government agency securities - those issued by Fannie Mae, Freddie Mac and the like and U.S. Treasury securities of equivalent maturity is often used as an early indicator. Normally, the securities from government agencies are viewed as only very slightly more risky and less liquid than Treasury issues themselves. But again, starting in August 2007, the gap doubled from its typical range of 15 to 25 basis points to more than 40 basis points. As the crisis intensified through the fall and winter, the so-called "agency spread" exploded to more than 90 basis points in March 2008. The change represented a "flight to quality," in which investors and financial institutions shunned everything but U.S. Treasury securities themselves.

It would seem that the standard monetary tools - the cut in the cost of discount borrowing and the increase in the term of the loans announced on August 17, 2007, followed by cuts in the federal funds rate target starting in mid-September 2007 - should have addressed the problem. However, there was no return to normalcy. Moreover, the problems of risk and credit shortage worsened through the late fall 2007 and early winter 2008. Thus, Fed officials began a series of less conventional actions that are not in the current textbook descriptions of monetary policy. These actions include reducing the premium on primary (discount) lending from 100 to 50 and then to 25 basis points above the federal funds rate target, as well as an increase in the term of the lending from overnight to 30 and then 90 days. It also led to the creation of several Term Auction 
Facilities (TAF). Thus, the recent financial crisis, naturally raises the question: What if anything can be done in terms of economic policy to prevent future financial instabilities?

\section{ECONOMIC POLICIES TO PREVENT FINANCIAL INSTABILITIES}

The 2007-2008 financial crisis and subsequent recession suggests that unregulated financial markets lead to financial crises. Further given the post WWII social compact which makes government responsible for dampening the impact of the business cycle, financial crises will induce the government to bail out those parts of the financial sector which are considered too big to fail or too interconnected to fail in order to dampen the impact of financial shocks on the real economy. This government response creates a moral hazard problem. There are four possible solutions: (1) break the social compact, i.e. get the government out of the business of attempting to stabilize the economy and bailing out financial institutions; (2) continue bail outs in time of crisis but do not increase regulation; (3) still bail out financial institutions in time of crisis but increase government regulation of financial markets and finally (4) follow an extensive public policy agenda in the spirit of $\mathrm{H}$. Minsky. The first solution is a return to the pre-social welfare state monetary and fiscal policies of the $19^{\text {th }}$ century and is very unlikely to happen. The second solution is one that perhaps some people in the financial sector would be prefer but it would likely result in even bigger financial crises in the future with resulting bigger government budget deficits and monetary overhang potentially leading to a increased uncertainty, higher inflation and/or prolonged slumps. The third solution seems practical. Even conservative economists have said that regulation of the financial sector needs to be reformed. The Minsky (1986) approach and its recent reinterpretation by Tymoigne and Wray (2009) calls for significant government initiatives beyond just regulation.

Looking forward a strong case can be made for changes in both monetary policy and financial regulation. The recent massive bailout of the U.S. financial sector has surely created the expectation that in the future the government will cover the bad outcome of any financial position taken by a too large to fail or too interconnected to fail financial institution. This expectation creates a moral hazard problem that must be dealt by financial regulation. Not to do so would imply potentially greater future financial crises and bailouts since managers of financial institutions under current regulations have incentive to take risks where bad outcomes are borne by tax payers.

To avoid a repeat of the current crisis a consensus is building for a new monetary policy regime that combines the standard goals of price stability and maximum sustainable growth as laid out in the Taylor rule with micro-prudential regulation and macro-prudential monitoring. Suggested micro-prudential regulation typically includes two main parts: (1) regulation to make leverage of financial institutions counter rather than pro-cyclical and (2) changes in financial market executive compensation to make managers internalize the potential negative externality they generate by taking risks. In other words managers need to lose a substantial portion of their income when the trades they make turn out ex post to be bad. The events of the recent financial crisis suggest that the leverage of non-financial institutions, such as the size of real estate down payments needs to be regulated as well. The often suggested macro-prudential monitoring is for 
regulators, such as the Fed, to monitor the trades of financial institutions. Many institutions making the same trade, i.e. the same bet, results in high systemic risk to all if the trade goes bad. Such monitoring could potentially lead to changes in micro-prudential regulation such as requiring firms to hold more capital, i.e. reduce leverage when financial institutions are taking a similar financial position based on similar assumptions (such as all betting that real estate prices will continue to rise). However since micro prudential regulation informed by macro-prudential monitoring is likely to decrease the profitability, size and political influence of the financial sector such changes in regulation have met and will continue to meet substantial resistance from members of the financial community. The future is likely to bring more financial crises. How severe they will be depends on how regulation is adjusted in response to the current crisis.

\section{CONCLUSIONS}

The financial crisis of 2007-2009 has upset the view that the "Great Moderation" in the volatility of real GDP growth and inflation was due to financial innovations and appropriate monetary policy. Ironically now many economists think that financial innovations and monetary policy caused the financial crisis and consequently the Great Recession. Hence the role of financial regulation and monetary policy plays in financial markets and the economy is being reconsidered. In the future monetary policy may respond directly to financial asset price booms and financial markets may be more tightly regulated. Getting the monetary and financial regulation policy mix right will be critical if future financial crises are to be avoided. 


\section{References:}

Adrian, T. and H. Shin (2009). "Liquidity and Leverage," Journal of Financial Intermediation, forthcoming.

Akerlof, G. and R. Shiller (2009), Animal Spirits: How Human Psychology Drives the Economy and Why it Matters for Global Capitalism, Princeton: Princeton University Press.

Bernanke, B. (2004) "The Great Moderation", Remarks by at the Meetings of the Eastern Economic Association, Washington, D.C., February 20, 2004

Bernanke, B. (2010), "Monetary Policy and the Housing Bubble", January 3, Speech at the Annual Meeting of the American Economic Association, Atlanta, Georgia.

Bernanke, B. and M. Gertler (1989). "Agency Costs, Net Worth, and Business Fluctuations," American Economic Review, vol. 79, pp.14-31.

Bordo, M., B. Eichengreen, D. Klingebiel and M. Martinez-Peria (2001). "Is the Crisis Problem Growing More Severe?” Economic Policy, April 2001, 53-82.

Brunnermeier, M. (2009). "Deciphering the Liquidity and Credit Crunch 2007-08," Journal of Economic Perspectives, vol. 23, pp. 77-100.

Buiter, W.H., (2007), "Lesson from the 2007 Financial Crisis", CEPR Policy Insight, No. 18.

Geanakoplos, J. (2009), “The Leverage Cycle”, Cowles Foundation Discussion Paper No. 1715.

Kaminsky, G. L. and Reinhart. C. M., (1999), “The Twin Crises: The Causes of Banking and Balance of Payments Problems", American Economic Review vol. 89, pp. 473-500.

Kiyotaki, N. and J. Moore (1997). "Credit Chains,” Journal of Political Economy, vol. 99, pp. 220-264.

Minsky, H. (1986), Stabilizing an Unstable Economy, New Haven: Yale University Press.

Reinhart, C.M., and Rogoff, K.S., (2008), "Is the 2007 U.S. Sub-prime Financial Crisis So Different? An international Historical Comparison”, NBER Working Paper.

Reinhart, C., and K. Rogoff (2008a). "This Time is Different: A Panoramic View of Eight Centuries of Financial Crises,” NBER Working Paper 13882. 
Reinhart, C., and K. Rogoff (2008b). "Banking Crises: An Equal Opportunity Menace," NBER Working Paper 14587.

Reinhart, C., and K. Rogoff (2009). "The Aftermath of Financial Crises," American Economic Review, forthcoming.

Taylor, J. (2008). "The Financial Crisis and the Policy Responses: An Empirical Analysis of What Went Wrong," working paper, Stanford University.

Tymoigne and L. Randall Wray (2009), "It Isn't Working: Time for More Radical Policies", The Levy Economics Institute Public Policy Brief No.105A. 